\title{
Qualitative analysis of Adenomatous Polyposis Coli promoter: Hypermethylation, engagement and effects on survival of patients with esophageal cancer in a high risk region of the world, a potential molecular marker
}

\author{
Maryam Zare 1,2, Ferdous Rastgar Jazii*1, Mohammad Reza Alivand1,2, \\ Negin Karimi Nasseri ${ }^{3}$, Reza Malekzadeh ${ }^{4}$ and Mansour Yazdanbod ${ }^{5}$
}

Address: ${ }^{1}$ Department of Biochemistry, National Institute of Genetic Engineering \& Biotechnology (NIGEB), Tehran, Iran, ${ }^{2}$ Division of Cell and Molecular Biology, Khatam University, Tehran, Iran, ${ }^{3}$ Donnelly Center for Cellular and Biomolecular Research (CCBR), University of Toronto, Toronto, Canada, ${ }^{4}$ Digestive Diseases Research Center, Shariati Hospital, Medical University of Tehran, Tehran, Iran and ${ }^{5}$ Department of Surgery Shariati Hospital, Medical University of Tehran, Tehran, Iran

Email: Maryam Zare - m_zare@nigeb.ac.ir; Ferdous Rastgar Jazii* - rastgar@nigeb.ac.ir;

Mohammad Reza Alivand - mohammadreza_alivand@yahoo.com; Negin Karimi Nasseri - karimi_negin@yahoo.com;

Reza Malekzadeh - malek@ams.ac.ir; Mansour Yazdanbod - rastgar@nigeb.ac.ir

* Corresponding author

Published: 17 January 2009

BMC Cancer 2009, 9:24 doi:10.1/86//47/-2407-9-24

This article is available from: http://www.biomedcentral.com/I47I-2407/9/24

(C) 2009 Zare et al; licensee BioMed Central Ltd.

This is an Open Access article distributed under the terms of the Creative Commons Attribution License (http://creativecommons.org/licenses/by/2.0), which permits unrestricted use, distribution, and reproduction in any medium, provided the original work is properly cited.
Received: 20 July 2008

Accepted: 17 January 2009

\begin{abstract}
Background: Squamous cell carcinoma of esophagus (SCCE) occurs at a high incidence rate in certain parts of the world. This feature necessitates that different aspects of the disease and in particular genetic characteristics be investigated in such regions. In addition, such investigations might lead to achievement of molecular markers helpful for early detection, successful treatment and follow up of the disease. Adenomatous Polyposis Coli (APC) promoter hypermethylation has been shown to be a suitable marker for both serum and solid tumors of adenocarcinoma of esophagus. We investigated the status of APC promoter hypermethylation in Iranian patients, compared the results with the former studies, and evaluated its applicability as a candidate molecular marker by examining association between survival of SCCE patients and APC promoter methylation.
\end{abstract}

Methods: For evaluating the status of $A P C$ promoter hypermethylation and its association with SCCE, a qualitative methylation specific PCR (MSP) was used. DNA was extracted and digested with an appropriate restriction enzyme, treated with sodium bisulfite in agarose beads and amplified in two-step PCR reaction by applying either methylated or unmethylated promoter specific primers. Universally methylated DNA and methylase treated blood DNA of healthy donors were used as positive controls as well. Survival of patients was followed up for two years after treatment and survival rate of patients with methylated APC promoter was compared with that of unmethylated patients.

Results: Assessment of APC promoter methylation revealed that normal tissues were unmethylated, while twenty out of forty five $(44.4 \%)$ tumor tissues were hypermethylated either in one or both alleles of APC. Among the tissues in which methylation was detected, seven were hypermethylated in both alleles while the other thirteen were hypermethylated in one of the two 
alleles of APC. Analyzing two-year survival rate of patients with respect to promoter hypermethylation showed a lower rate of survival for patients with methylated APC promoter following their treatment. Further investigation into the association between promoter hypermethylation and tumor differentiation status indicated that patients with well differentiated tumors were more likely to develop promoter hypermethylation.

Conclusion: Observing similar level of APC promoter hypermethylation in patients with SCCE in this high risk region and comparing it with other parts of the world could support the hypothesis that a common molecular mechanism might be involved in tumorigenesis of SCCE. In addition, the higher rate of two-year survival for patients with unmethylated APC promoter as well as its relationship with tumor differentiation would suggest that this tumor suppressor could be an appropriate candidate molecular marker for evaluating tumor malignancy and predicting survival of patients subsequent to treatment.

\section{Background}

A high incidence rate of SCCE has been reported for the so-called Asian esophageal cancer belt; the highest rate of which was reported from Iran [1-5]. In addition, recent reports have evidenced an increasing incidence of esophageal cancer in developed countries, especially adenocarcinoma of esophagus [6-8]. Several genetic and epigenetic alterations have been suggested to play an important role in the carcinogenesis of esophageal and other gastrointestinal (GI) tumors; affecting different oncogenes, tumor suppressor genes, apoptosis regulating genes or mismatch repair genes such as APC, P53, P16, DCC, RB, MCC, BRCA and MTS1/CDK41 [9-18]. Hypermethylation of CpG islands in promoter regions of genes is a common epigenetic event of gene silencing in both types of esophageal cancers and impacts a wide range of important genes such as those involved in matrix remodeling like TIMP3 $[19,20]$, ligand dependent suppressor genes for instance DCC [21], cell adhesion genes including cadherins (CDH1) and integrins [22-24], cell cycle regulator genes such as $p 14, p 16[20,23,24]$, apoptosis associated genes like $D A P K$, DNA repair and mismatch repair genes such as MGM, hMLH1 [20,23-25], xenobiotic metabolism engaged genes for instance GSTP1 [24] and nel-like1gene [26]. Epigenetic silencing of tumor suppressor genes has been shown to be associated with tumor invasiveness, growth, neovascularization, metastatic behavior and in particular, might be the cause of tumor recurrence after treatment, impacting overall patient survival [27-30].

Among those genes which are subject of epigenetic regulation, APC promoter hypermethylation occurs in all organs of GI cancers, both in hereditary and sporadic syndromes. This might indicate the importance of $A P C$ inactivation in tumorigenesis of these organs [31]. Moreover, recent reports indicate that $A P C$ is an important prognostic indicator for unfavorable clinicopathological outcome and tumor recurrence in several types of cancers [29,30]. $A P C$ along with several other hypermethylated genes play a prognostic indicatory role in squamous cell [22] and adenocarcinoma of esophagus [26], bladder [30], and lung cancers [29]. In fact, in adenocarcinoma of esophagus, APC promoter hypermethylation has been observed in $92 \%$ of cases [32]. This indicates that inactivation of APC plays a key role in the carcinogenesis of esophageal cancers and could be considered as a candidate molecular marker.

The Adenomatous Polyposis Coli (APC) tumor suppressor gene, maps on chromosome 5q21-22, has been investigated in several types of cancers and in particular colorectal cancers. While loss of heterozygosity $[11,18,33,34]$ along with mutational inactivation $[35,36]$ has been suggested for APC in esophageal cancer, nevertheless, mutations in APC are rare in this cancer [37-39]. Investigations have shown that inactivation of $A P C$ leads to increased $\beta$-catenin transcriptional activity and subsequent loss of cellular growth control. In normal cells, free $\beta$-catenin anchors to APC tripartite complex, composed of Axin-APC-GSK3- $\beta$ and undergoes phosphorylation by glycogen synthase kinase $3-\beta$ (GSK3- $\beta$ ), followed by proteasomal degradation, which results in reduction of free $\beta$ catenin in cytoplasm and thus, leading to silencing of the Wnt signaling target genes [40]. In contrast, loss of APC results in nuclear accumulation of $\beta$-catenin, which subsequently binds to Tcf-Lef ( $\mathrm{T}$ cell factor/lymphoid enhancer factor) family of transcription factors, culminating in the activation of transcription and ultimately uncontrolled cell growth $[41,42]$.

With regards to epigenetic regulation of $A P C$ and other tumor suppressor genes, so far as we know there is no previous report from this high risk region of the world. This is the first effort that has focused on epigenetic regulation of $A P C$ as an example of tumor suppressor genes such as $P 15^{I N K b}$. We have recently begun to investigate their possible roles in carcinogenesis of SCCE in this region. The present report is the first attempt toward applying qualitative methylation specific PCR to reveal the methylation status of $A P C$ promoter within an Asian population 
highly at risk for developing SCCE. Our results show that the frequency of APC promoter methylation is almost the same as other regions, in particular the Western world. The results of this study also indicate that APC promoter methylation could be considered as a potential molecular marker for follow up the progress and survival of patients in consequence to their treatment.

\section{Methods}

\section{Patients and specimens}

45 patients including 27 men ranging in age from 23 to 80 (average of 61.1) and 18 women ranging in age from 45 to73 (average of 61.7) at the time of diagnosis were included in this study. Tumor tissues along with their adjacent normal tissues were used for analysis. Tissue samples were obtained from patients whom had not received chemo or radiotherapy before operation. Following surgery, tissue samples were snap frozen in liquid nitrogen and kept at $-70^{\circ} \mathrm{C}$ until the time of DNA extraction. Tissues were included 32 poorly differentiated, 5 moderately and 8 well differentiated tumors according to the World Health Organization criteria (WHO, 1977). All samples were diagnosed as SCCE and status of differentiation were confirmed by pathological examination. Peripheral blood samples of healthy donors were collected as negative control. The same blood samples were also used for further treatment with DNA methylase for evaluating bisulfite treatment procedure. The survival rate of patients was monitored for two years. All patients and healthy donors of blood samples gave consent according to institutional guidelines and the study was approved by the research ethics committee of Digestive Disease Research Center (DDRC) of Medical University of Tehran.

\section{DNA Isolation and digestion}

Genomic DNA was extracted from the ground frozen normal and tumor tissues following digestion with proteinase $\mathrm{K}$ and phenol/chloroform protein precipitation $[43,44]$. Blood DNA was extracted as previously described [45]. Subsequently, extracted DNA of either tumor or normal tissues was digested with Hind III (Fermentase Company), for which no restriction site is present in the entire 1556 bp of APC promoter. Digestion with HindIII enhances DNA denaturation and results in better bisulfite treatment as well.

\section{Agarose/DNA beads preparation}

One $\mu \mathrm{g}$ of the digested genomic DNA was boiled for 5 min, immediately chilled on ice, and subsequently incubated in $0.3 \mathrm{M} \mathrm{NaOH}$ for $15 \mathrm{~min}$ at $50^{\circ} \mathrm{C}$. Two volumes of the melted 2\% low melting point (LMP) agarose (Roche Company) dissolved in ddH2O were pipetted into the mixture. DNA/agarose mixtures containing 100-200 ng of DNA were injected into chilled mineral oil to form agarose beads [46].

\section{Sodium bisulfite treatment of agarose beads}

Deamination of DNA was performed using freshly made bisulfite solution (2.5 M sodium metabisulfite and 125 $\mathrm{mM}$ hydroquinone, $\mathrm{pH} 5$ ) at $50^{\circ} \mathrm{C}$ in the dark. Bisulfite treatment of agarose beads at moderate temperature $\left(50^{\circ} \mathrm{C}\right)$, for short time, reduces DNA degradation while still keeping it in the single stranded conformation required for complete treatment. Furthermore, since treated agarose beads could directly be used in PCR reaction, there is no need for precipitation of treated DNA which usually accompanied by some loss [46-48]. Aliquots of $200 \mu$ l bisulfite solution were added to vials containing a single bead and incubated at $50^{\circ} \mathrm{C}$ for $4 \mathrm{~h}$ in the dark $[32,46]$. Further treatment was stopped by equilibrating the beads with TE buffer (10 mM Tris HCL, $1 \mathrm{mM}$ EDTA, pH 8) for 6 times, each time for $15 \mathrm{~min}$, followed by desulfonation with $0.2 \mathrm{M} \mathrm{NaOH}$, and neutralization with $1 / 5(\mathrm{~V} / \mathrm{V}) 1 \mathrm{M} \mathrm{HCl}$ for $15 \mathrm{~min}$, this procedure was repeated twice. Finally, each bead containing modified DNA was washed twice with TE buffer and then twice with ddH2O, consecutively, each time for $15 \mathrm{~min}$ [46]. Beads were kept in a small volume of TE $(\mathrm{pH} 8)$ at $4^{\circ} \mathrm{C}$ and used in less than 3 weeks without any effect on the quality of MSP.

\section{Methylation Specific PCR}

Bisulfite treated DNA from either of following samples was used in methylation specific PCR [49]. Samples were composed of normal and tumor tissues along with blood of healthy donors as negative control. In addition, methylated DNA (CpGenome Universal methylated DNA, Chemicon) and blood DNA modified by CpG methylase (New England Biolabs) were used as positive control and control of bisulfite treatment efficiency.

Methylation specific PCR was carried out using promoter $1 \mathrm{~A}$ of APC in two-step amplification procedure. A primary amplification was followed by secondary methylation specific PCR. Bisulfite treatment was performed before primary amplification because DNA polymerase uses deoxycytosine in the reaction mixture wherever a guanine is present in the template. As a result, it becomes impossible to discriminate methylated from unmethylated cytosines if bisulfite treatment is done after primary amplification. Moreover, treatment after primary amplification also results in loss or degradation of DNA. For primary amplification, the region of promoter $1 \mathrm{~A}$ without CpG dinucleotides was used for forward and reverse primer design. This approach not only verifies proper treatment of DNA but also provides an adequate template for the second round of PCR, in which methylated cytosines are differentiated from unmethylated ones by applying methylated $\mathrm{CpG}$ dinucleotides specific primers. Two sets of primers were designed for primary amplification. The first set of primers were the forward primer; 5 '- 
TTT GTT TGT TGG GGA TTG GGG T-3', and the reverse primer; 5'-AAA CCC TAT ACC AAA AAA AAA CCA TC-3', resulting in a product of $402 \mathrm{bp}$. The second set of primers for primary amplification were the forward primer; 5 '-GTT AGG GTT AGG TAG GTT GTG-3', and the reverse primer; 5'-AAA ACA ATA CAA AAA AAA ACC ACC TTC-3', leading to a 320 bp product. Bisulfite treated DNA was amplified in a $50 \mu \mathrm{l}$ reaction volume containing $1 \times$ reaction buffer, $0.2 \mathrm{mM}$ each dNTP, $1 \mathrm{mM} \mathrm{MgCl} 2,8 \mathrm{mM} \beta$-mercaptoethanol (2-ME), $0.8 \mu \mathrm{g} / \mathrm{ml}$ bovine serum albumin (BSA), $8 \%$ dimethyl sulphoxide (DMSO) and $20 \mathrm{pmol} / \mathrm{reaction}$ of either sets of primers designed for primary amplification. Applying a mixture of several PCR enhancers (DMSO, 2ME, BSA) increases the yield of MSP and the specificity of PCR products [50-52]. This is especially important in the case of GC-rich targets as well as for regions capable of forming secondary structure, which often result in little or no amplification. Cycling condition was composed of hot start at $94^{\circ} \mathrm{C}$ for 5 min before addition of 1.2 units of Taq polymerase (Roche), 10 cycles for step I of amplification was composed of denaturation at $94^{\circ} \mathrm{C}$ for $50 \mathrm{sec}$, annealing at $62^{\circ} \mathrm{C}$ for $1 \mathrm{~min}$ (touch down $0.2^{\circ} \mathrm{C} / \mathrm{cycle}$ ), extension at $72^{\circ} \mathrm{C}$ for $1 \mathrm{~min}$ followed by 27 cycles of step II of amplification with denaturation for $50 \mathrm{sec}$ at $94^{\circ} \mathrm{C}, 1 \mathrm{~min}$ annealing at $58^{\circ} \mathrm{C}, 1 \mathrm{~min}$ extension at $72^{\circ} \mathrm{C}$ followed by 10 min final extension at $72^{\circ} \mathrm{C}$.

Primary amplification condition for the second set of primers was the same as above except for application of 2 $\mathrm{mM} \mathrm{MgCl2}$, and slight reduction in annealing temperature of steps I and II. Amplification was composed of 10 cycles of $50 \mathrm{sec}$ primary denaturation at $94^{\circ} \mathrm{C}, 1 \mathrm{~min}$ annealing at $58^{\circ} \mathrm{C}$ (touch down $0.2^{\circ} \mathrm{C} /$ cycle) and $1 \mathrm{~min}$ extension at $72^{\circ} \mathrm{C}$ as step I of amplification, followed by 27 cycles of $50 \mathrm{sec}$ denaturation at $94^{\circ} \mathrm{C}, 1 \mathrm{~min}$ annealing at $56^{\circ} \mathrm{C}, 1 \mathrm{~min}$ extension at $72^{\circ} \mathrm{C}$ and $10 \mathrm{~min}$ final extension at $72^{\circ} \mathrm{C}$, as step II. Eventually, PCR products were run in $2 \%$ agarose, stained with ethidium bromide and observed under UV light.

PCR products of primary amplification were used for MSP. The primers for amplification of methylated cytosines of promoter $1 \mathrm{~A}$ were the forward primer; $5^{\prime}$ TAT TGC GGA GTG CGG GTC 3', and the reverse primer; 5' TCG ACG AAC TCC CGA CGA 3'. The unmethylated CpG dinucleotide specific primers were the forward primer; $5^{\prime}$ GTG TTT TAT TGT GGA GTG TGG GTT 3', and the reverse primer; 5' AAC CAA TCA ACA AAC TCC CAA CAA 3'.

MSP was performed in $50 \mu \mathrm{l}$ PCR reaction mixture containing $1 \times$ reaction buffer, $0.2 \mathrm{mM}$ each dNTP, $6 \mathrm{mM}$ $\mathrm{MgCl} 2,8 \mathrm{mM} \beta$-mercaptoethanol, $0.8 \mu \mathrm{g} / \mathrm{ml}$ BSA, $8 \%$ DMSO, $20 \mathrm{pmol} /$ reaction mixture of methylated or unmethylated specific primers and 1.2 units of Taq polymerase. PCR condition was hot start denaturation at $94^{\circ} \mathrm{C}$ for $5 \mathrm{~min}, 10$ cycles of $50 \mathrm{sec}$ denaturation at $94^{\circ} \mathrm{C}$, $40 \mathrm{sec}$ annealing at $56^{\circ} \mathrm{C}$ (touch down $0.2^{\circ} \mathrm{C} /$ cycle), 40 $\mathrm{sec}$ extension at $72^{\circ} \mathrm{C}$ followed by 28 cycles of $50 \mathrm{sec}$ denaturation at $94^{\circ} \mathrm{C}, 40 \mathrm{sec}$ annealing at $54.5^{\circ} \mathrm{C}, 40 \mathrm{sec}$ extension at $72^{\circ} \mathrm{C}$ and $10 \mathrm{~min}$ final extension at $72^{\circ} \mathrm{C}$. Each set of primers (methylated or unmethylated specific primers) was used for amplification of tumor and normal tissue samples as well as negative and positive controls. PCR products were run in $2 \%$ agarose gel, stained with ethidium bromide and visualized by UV illumination.

\section{Statistical analysis}

Fisher's exact test was used to examine the association between APC promoter hypermethylation and mortality rate in SCCE patients. Moreover, the Pearson Chi-Square test was performed to find out possible correlation. Statistical significance was defined as $P<0.05$ for Fisher's exact test and $P<0.001$ for Pearson Chi-Square test.

\section{Results}

To increase specificity of MSP procedure, four sets of primers were designed for promoter $1 \mathrm{~A}$ of APC (NCBI accession No: U02509) (Figure 1). Two sets of primers were used in primary amplification leading to either 402 or 320 bp products, which were used in subsequent amplification by applying specific primers for either methylated or unmethylated APC promoter (Figures 1 and 2). The primers used in the primary amplification were designed against a part of the promoter sequence without $\mathrm{CpG}$ dinucleotides. This approach eliminated interference of methylated cytosines and the possible insufficiency of bisulfite treatment. In addition, enhanced discrimination of methylated from unmethylated cytosines became possible in subsequent MSP by applying primers specifically designed against part of the promoter with a high number of CpG dinucleotides (Figure 1). MSP products were either $98 \mathrm{bp}$ for methylated cytosines or $111 \mathrm{bp}$ in case of unmethylated.

Carrying out MSP on DNA extracted from normal tissues, $111 \mathrm{bp}$ products were obtained, which indicate that normal tissues are unmethylated (Figure 3). In contrast, achievement of $98 \mathrm{bp}$ amplification products for 20 out of 45 tumor tissues points out that $44.4 \%$ of tumor tissues are methylated either in one or both alleles of APC. Among methylated tumor tissues, 13 were heterozygous for the APC promoter; for which both $111 \mathrm{bp}$ and $98 \mathrm{bp}$ products were observed (Figure 4 ). This could happen due to two reasons; first, heterogeneity of tumor tissues regarding with their originated cells, such that both cells containing methylated and cells with unmethylated DNA are present in the same tissue. The second reason could be allelic heterozygosity of APC regarding with methylation. Conversely $7(16 \%)$ other tumor tissues were methylated for both alleles of $A P C$, indicating that their correspond- 


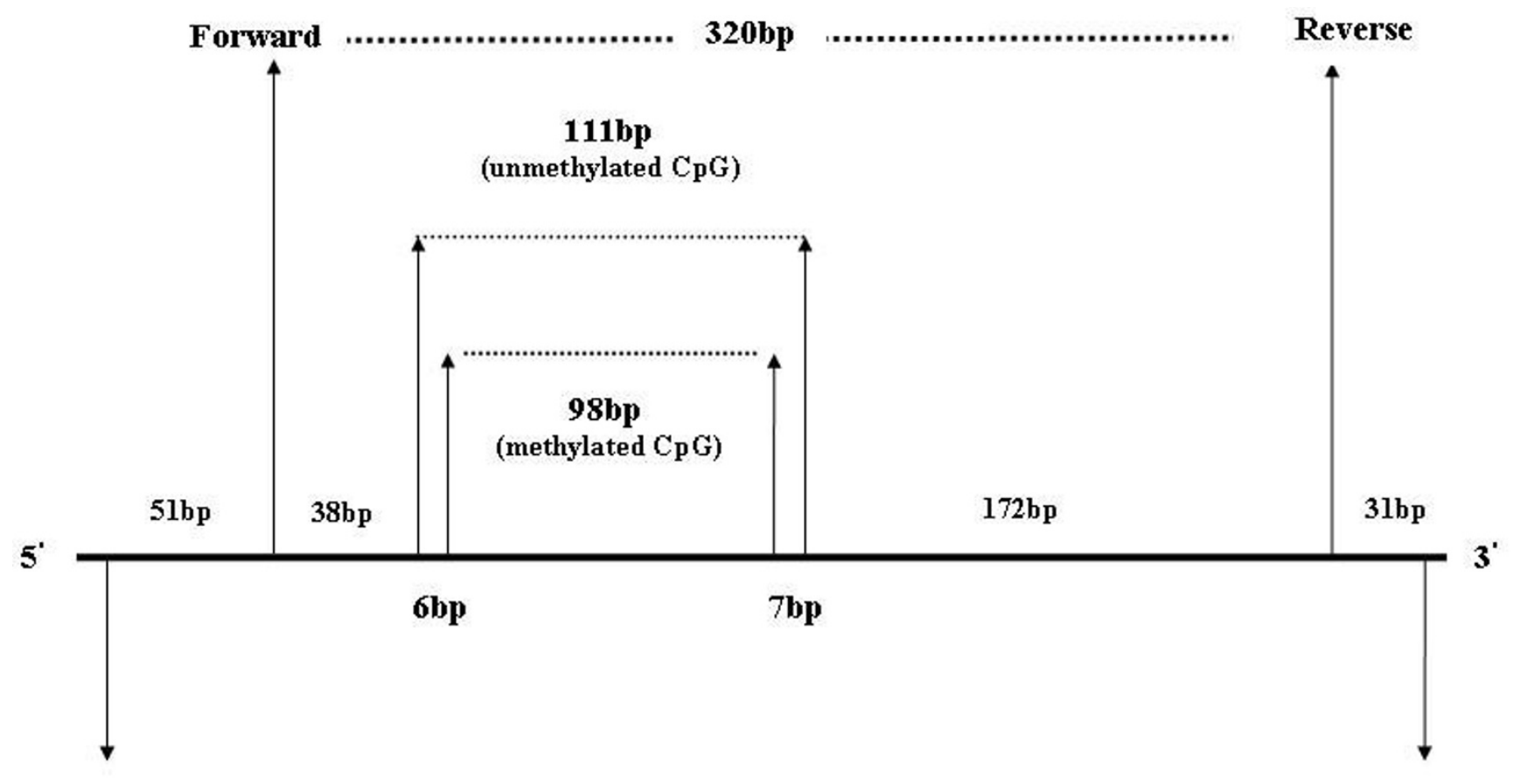

Forward

$402 \mathrm{bp}$

Reverse

\section{Figure I}

The profile of $A P C$ promoter and the amplified products. The products of primary amplification with primers designed for promoter sequence without CPG dinucleotides were either 402 or 320 bp. The product of the first step of PCR was used for the second step amplification by applying primers, which specifically distinguish methylated from unmethylated cytosines. The products of the second amplification were $98 \mathrm{bp}$ for methylated and III bp for unmethylated cytosine in CpG islands of promoter.

ing tissues were homogeneous and composed of only one type of cells (Figure 3).

To verify consistency of results, three controls were used; universally methylated DNA, blood DNA of healthy donors and DNA from the same donors treated with DNA methylase. As figure 5 shows following bisulfite treatment of blood DNA of healthy donors and carrying out MSP, it is negative for $A P C$ promoter methylation because it could only be amplified with unmethylated APC promoter specific primers. In contrast the same DNA could only be amplified by methylated APC promoter specific primers if it was treated with DNA methylase (Figure 5, lane 3). This provides evidence that bisulfite treatment was complete and MSP was properly carried out. Further support to our study was application of universally methylated DNA as positive control. Here amplification was only possible with methylated APC promoter specific primers. All the above controls verified that design of experiments was proper and the results are valid.

Pathological assessment of tissues showed that tumors were in different states of differentiation, such that 32
(71\%) cases were poorly differentiated, $5(11 \%)$ were moderately differentiated and $8(18 \%)$ others were well differentiated. Among poorly differentiated tumors, 13 (41\%) were methylated, while 19 (59\%) were unmethylated. This condition was also true for moderately differentiated tissue samples in which 2 out of $5(40 \%)$ tumors were methylated while $3(60 \%)$ others displayed unmethylated tumors. The highest rate of methylation was found in well differentiated tumors where 5 out of $8(62.5 \%)$ tissues were methylated (Table 1).

Following up survival of patients for two years revealed a clear relationship between patients survival and methylation status of APC promoter. Fisher's exact test, which examines the association between APC methylation circumstances and mortality of patients, showed the statistically significant correlation $(\mathrm{P}<0.05)$. In addition, the Pearson Chi-Square test indicted the same relation. This statistic $\left(X^{2}=6.86\right)$, at 2 degree of freedom $(\mathrm{df})$, revealed that there is a significant association $(p<0: 001)$ between presence of hypermethylated APC promoter and mortality rate among SCCE patients. 


\section{$\begin{array}{lllll}1 & 2 & M & 3 & 4\end{array}$}

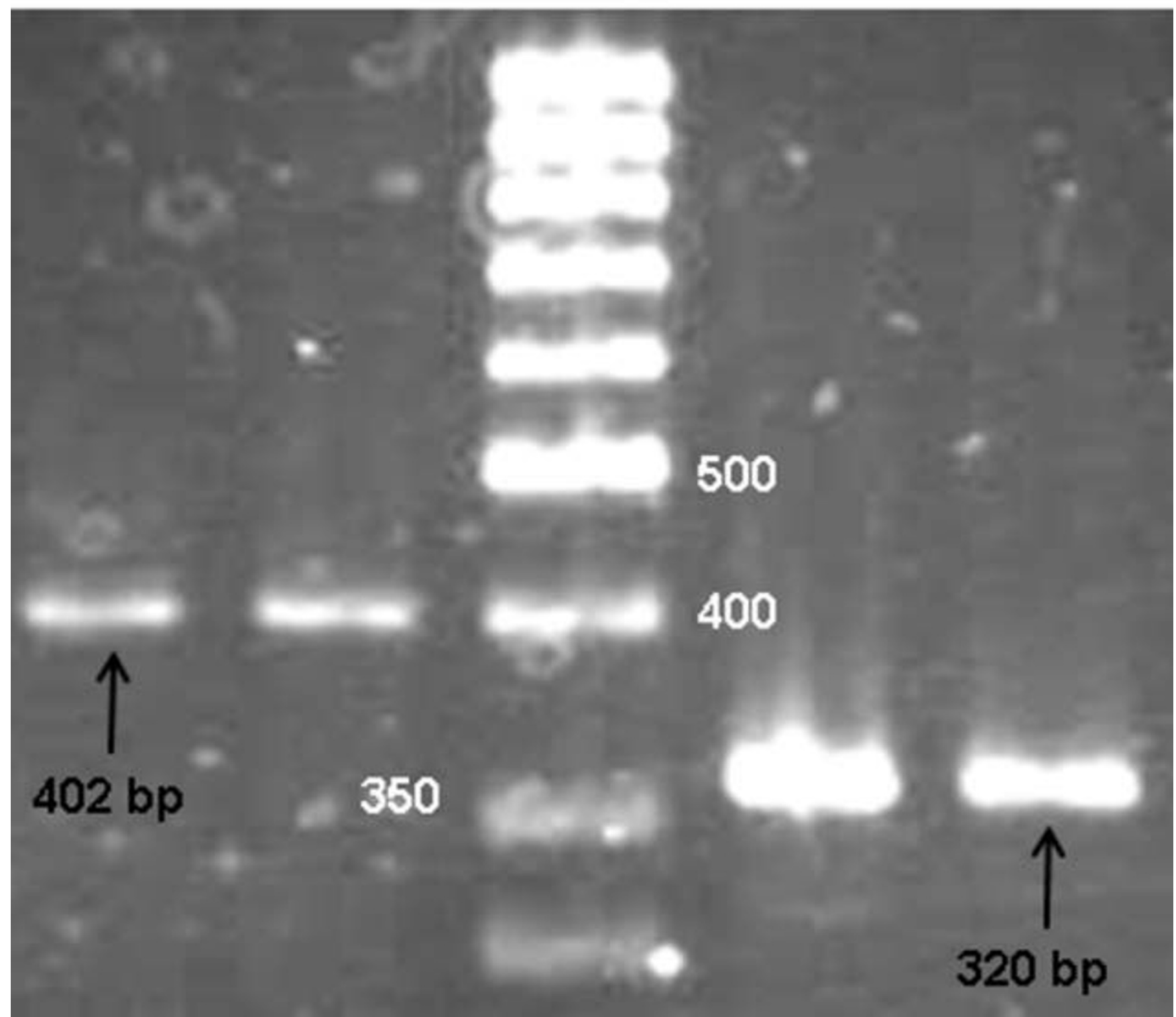

\section{Figure 2}

PCR products of primary amplification subsequent to bisulfite treatment. Lanes I and 2 show the 402 bp and lanes 3 and 4 the 320 bp PCR products. Either of the above PCR products could be used for secondary nested amplification.

As Table 1 shows, patients with unmethylated tumors, in all states of differentiation, are more likely to survive for two or more years after treatment. Moreover, as differentiation status turns from well to poor, survival rate of patients with methylated promoters increases, while the converse is true for unmethylated promoters. It should also be noted that in the case of patients with moderate and well differentiated tumors additional samples are required to be included in future studies until a true judgment could be made.

\section{Discussion}

Although epidemiological studies have indicated the highest incidence rate of SCCE occurs in Iran [1-5], nevertheless reports from this part of the world are limited. The present report is an extension to our former studies $[4,10]$ on the molecular etiology of SCCE in this region, aiming 


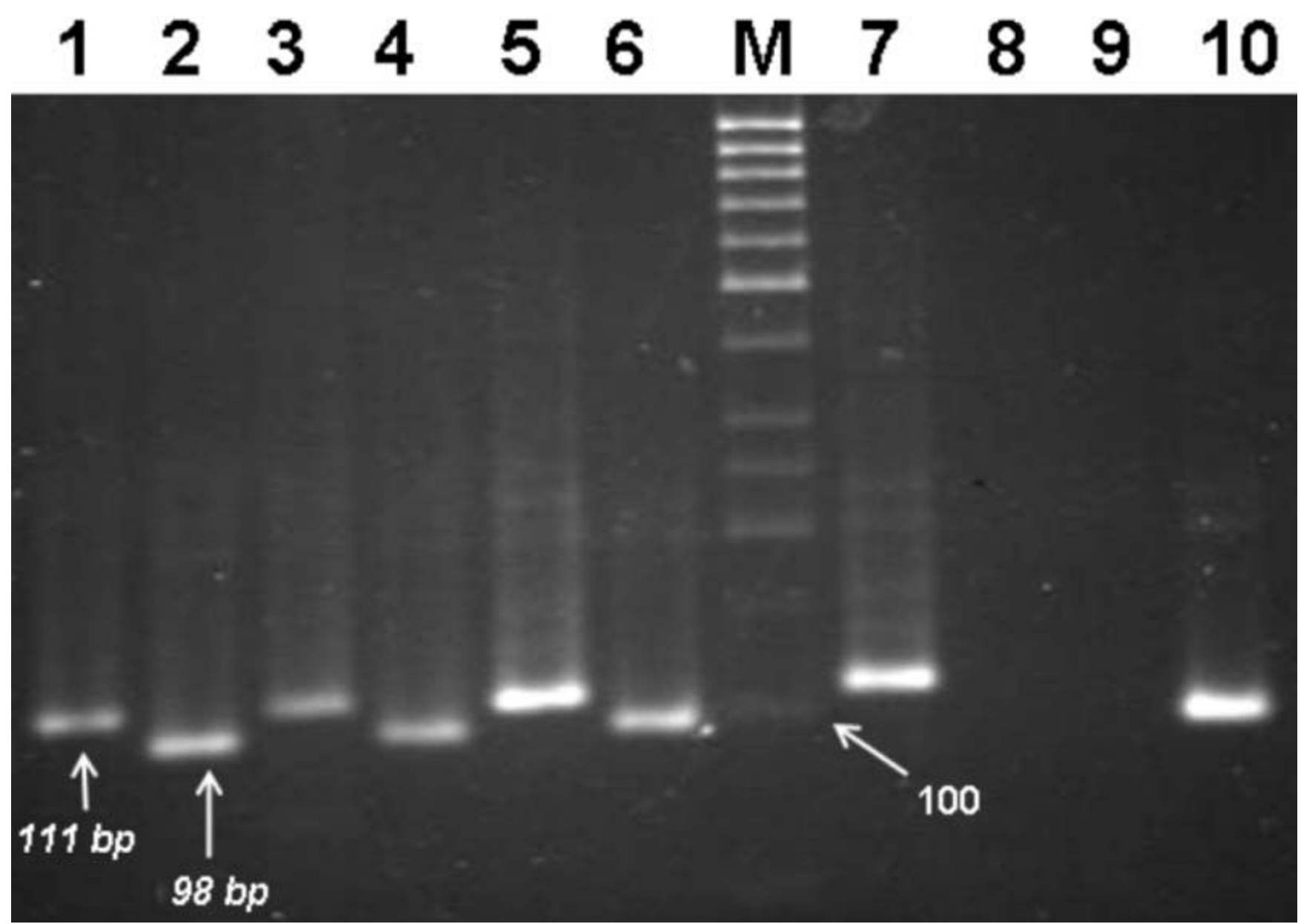

Figure 3

MSP assessment of tumors versus normal tissues of three patients along with controls. Lanes I, 3 and 5 show unmethylated APC promoter amplification product of normal nonmalignant tissues with a III bp PCR product. Lanes 2 , 4 and 6 are the corresponding methylated tumor tissues of APC promoter as could be observed with 98 bp PCR product. Lane 7; negative control (blood) which results in II I bp product. Lane I0; positive control (universally methylated DNA) with a 98 bp product. Lane M; molecular size marker 50 bp (Fermentase).

to identify potential molecular markers. It is well known that tumor suppressor genes are mostly affected in SCCE [9,11,13-17,34,53-57]. As part of a long-term study we have started analysis of APC promoter methylation among tumor suppressor genes such as $p 15^{I N K b}$ (data not shown) as well as cell cycle inhibitors such as $p 14, p 15$, $p 16$ and $p 21$. Epigenetic regulation of gene expression through promoter methylation is one of the key means of controlling genes during development and also transcriptional silencing of tumor suppressor genes in cellular transformation. Promoter methylation pattern varies in different types of cancers. The highest occurrence of methylation has been observed in GI cancers involving both sporadic and inherited types [58].

$A P C$ is among tumor suppressor genes whose inactivation occurs in esophageal cancer as well as other GI cancers
[31]. Inactivation of $A P C$ has been shown to be an early event in tumorigenesis of colorectal and gastric cancer [59-61], as could be observed with histopathological examinations and particularly in intestinal tumors in which sufficient levels of DNA methyltransferase activity play a role in the early polyp formation in $A P C^{\mathrm{Min} /+}$ mice [62]. Otherwise, APC hypermethylation has been observed in less advanced stages of both types of esophageal cancer, similar to $p 16$ and $h M L H 1$ genes $[20,31]$. Thus, APC could be considered as an appropriate predictive molecular marker especially for digestive tract cancers.

Eads and colleagues have previously shown APC promoter hypermethylation in Barrett's epithelium, either in metaplasia, dysplasia and adenocarcinoma of esophagus [54]. Meltzer's group [32] has demonstrated the signifi- 


\section{patient patient $\mathrm{N}$ control P control 1 2 3 $4 \mathrm{M}$ 56 7 8}

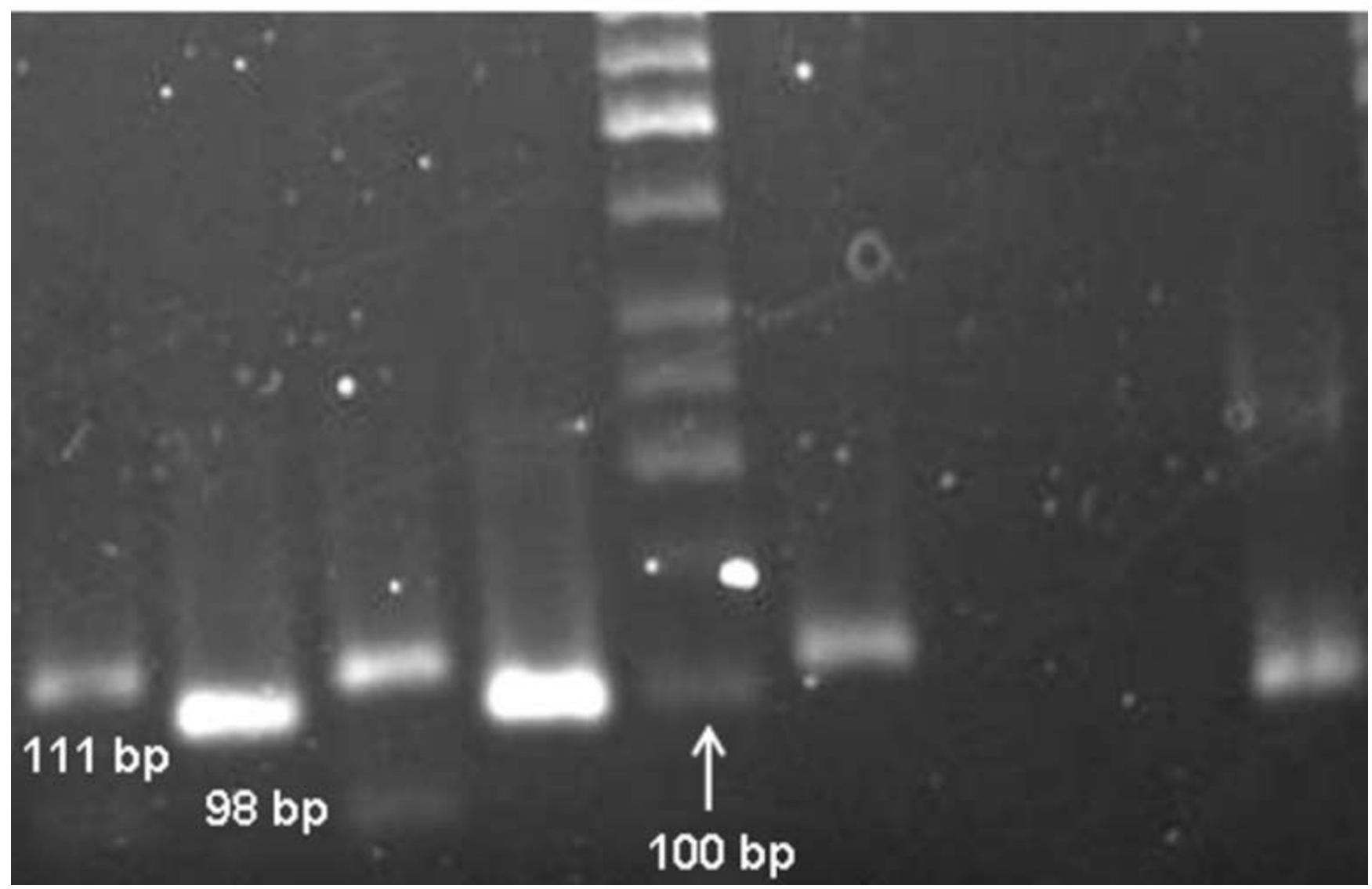

\section{Figure 4}

MSP products of several hemimethylated or cellularly heterogeneous tumor tissues. Both 98 bp MSP product of the methylated APC promoter and I I I bP MSP product of the unmethylated promoter could be observed in tumor tissues. Lanes I and 3 represent the MSP products of tumor tissues by applying unmethylated primers. Lanes 2 and 4 show the MSP products for the same tissues using methylated primers. Lanes 5 and 6; negative control (blood) which results in III bp product. Lanes 7 and 8; positive control (universally methylated DNA) with a 98 bp product. M; molecular size marker 50 bp (Fermentase).

cance of $A P C$ as a molecular marker for both serum and tissues of patients with adenocarcinoma of esophagus. Their study showed $92 \%$ hypermethylation of APC in adenocarcinoma. The same figure has also been obtained by Clement et al. [42], who have found APC promoter hypermethylation in all instances of Barrett's esophagus and in 95\% of adenocacinoma of esophagus. Further study on the mucosa of patients at risk for developing Barrett's esophagus, a condition which progresses to adenocarcinoma of esophagus, has shown $88 \%$ methylation of APC promoter [63]. Moreover, in recent studies APC methylation has been found to be an appropriate molecular marker for monitoring tumor recurrence in lung [29] and bladder [30]cancer in which the presence of hypermethylated APC in the serum of patients correlates with worse clinicopathological features of malignancy.

These findings have encouraged us to study the status of APC promoter methylation in SCCE as well as evaluating its possible role as a potential molecular marker. Results indicate that $44.4 \%$ of patients with SCCE exhibited hypermethylation in the APC promoter. These patients were at a greater risk of death in the two years following treatment than the unmethylated patients. This finding indicates that examination of APC promoter could be applicable as a potential predictive survival marker for 

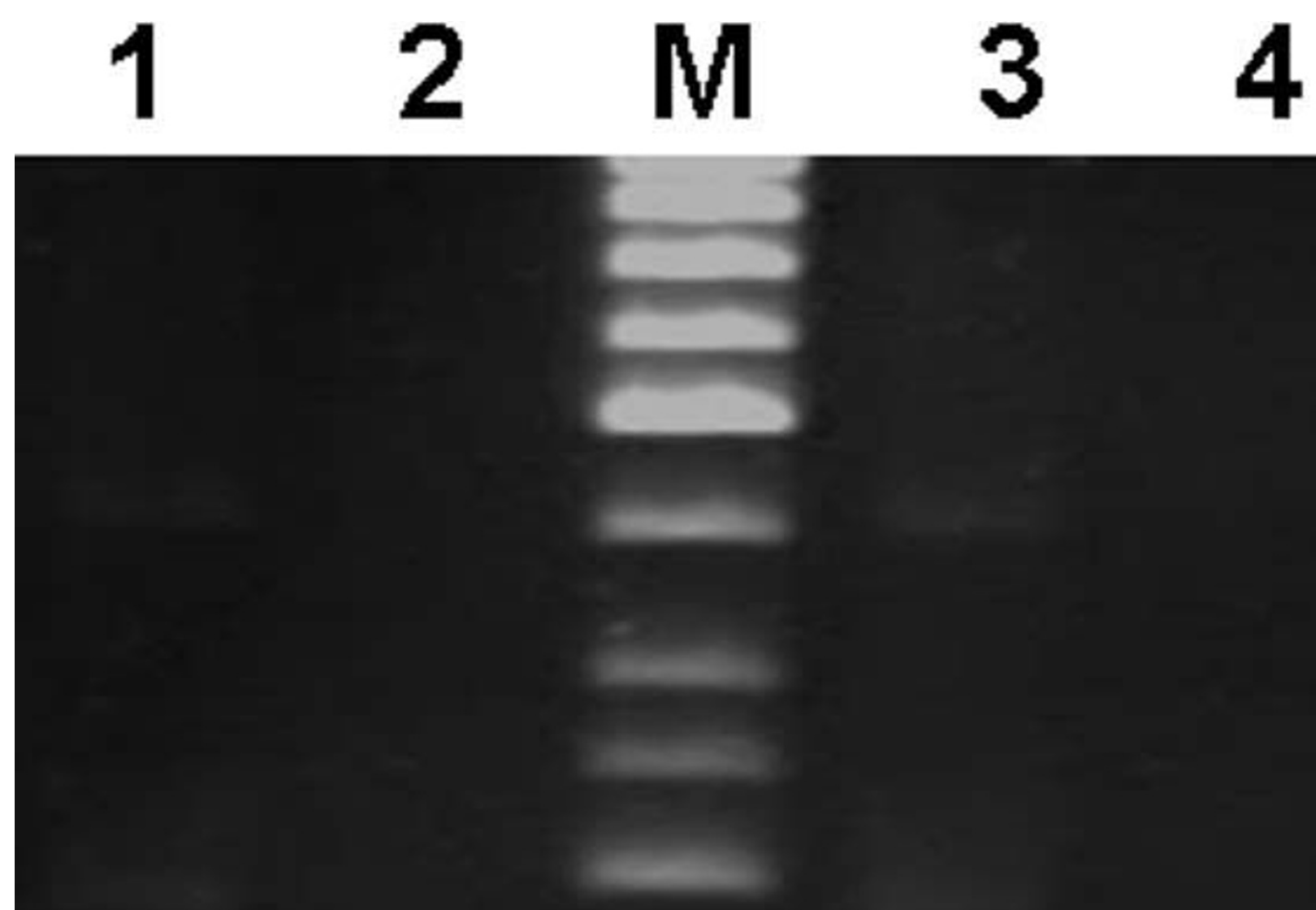

\section{0}

100

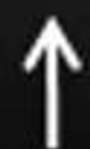

98 bp

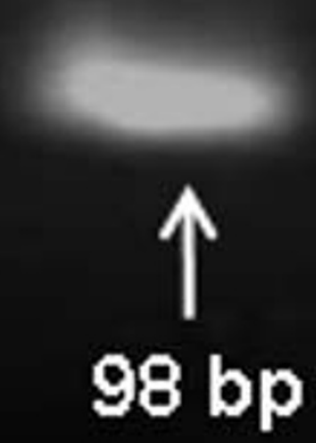

\section{Figure 5}

MSP results of two positive controls. Lane I; MSP product of universally methylated DNA by applying methylated cytosine specific primers. Lane 2; the same as lane I but unmethylated cytosine specific primers were used. lane 3; MSP product of blood DNA extracted from a healthy donor treated with DNA methylase (CPG methyl transferase) and application of methylated cytosine specific primers, lane 4; the same as lane 3 but unmethylated cytosine specific primers were used.

almost 50\% of SCCE. In addition, combining this marker with other potential markers such as p53 for which a high frequency $[10,16,33,64-66]$ of inactivation could be observed in SCCE would assist better treatment and fol- low up of disease. Achieving a $44.4 \%$ methylation of APC promoter might well point to the involvement of the same possible molecular alterations in the etiology of SCCE in the Iranian population as in other parts of the world. On 
Table I: Methylation status and two-year survival of patients following surgery.

\begin{tabular}{lllllll}
\hline Tumor differentiation status * & Total & Survival rate & Methylated tumors & Survival rate & Unmethylated tumors & Survival rate \\
\hline Poor & 32 & 24 & $13(40.6 \%)$ & $8(61 \%)$ & $19(59 \%)$ & $16(84 \%)$ \\
Moderate & 5 & 4 & $2(40 \%)$ & $2(40 \%)$ & $3(60 \%)$ & $2(67 \%)$ \\
well & 8 & 4 & $5(62 \%)$ & $1(20 \%)$ & $3(37.5 \%)$ & $3(100 \%)$ \\
\hline Total & 45 & 32 & $20(44 \%)$ & $11(55 \%)$ & $25(56 \%)$ & $21(84 \%)$ \\
\hline
\end{tabular}

*Differentiation classification according to the WHO criteria (World Health Organization, 1977)

the other hand, our observation for unmethylated normal esophagus epithelium is in agreement with Eads et al. [54], who have shown that normal esophageal epithelium is unmethylated for promoters such as APC, CDH1, ESR1, CDKN2A. Thus, it is rational to consider the methylation status of tumor suppressor genes' promoters as a potential marker for esophageal cancer.

Comparing our results with Meltzer's group [32] on SCCE reveals a close similarity (50\% versus $44.4 \%$ ), which might indicate APC to be among genes whose expression is affected at the same level in two distinct and geographically separate populations of the world. In addition, inactivation of $A P C$, which results in $\beta$-catenin transcriptional activation $[37,41,42,67]$, seems to be among prerequisites for esophageal carcinogenesis. Brabender et al. [28] have shown that high level of APC ptomoter hypermethylation is significantly associated with unfavorable clinical outcomes, lower survival rate and aggressive behavior of tumors. Our study also shows lower survival rate of patients with APC hypermethylation. The higher mortality rate of patients with methylated $A P C$ promoter indicates that $A P C$ is among determinant genes in esophageal carcinogenesis. Our former study on $p 53$ tumor suppressor gene [10] further supports this notion as well as other former studies that have indicated the importance of tumor suppressor genes in the etiology of SCCE [9$18,33,34,36]$.

Our additional study on $p 15^{\mathrm{INKb}}$ further shows the same pattern of promoter methylation in SCCE when, for example, our finding $(16.6 \%)$ is compared with other reports such as Xing et al. [56] who have found $17.6 \%$ and Nie et al. [68] who have shown $19 \%$ of $P 15^{I N K b}$ hypermethylation. These results further indicate similarity in the process of tumorigenesis of SCCE.

There are two promoters for transcription of APC; promoter $1 \mathrm{~A}$ and $1 \mathrm{~B}[69]$. In this study we focused on promoter $1 \mathrm{~A}$ because this promoter is known to play a major role in carcinogenesis [70]. Previous studies in colon, breast, lung, endometrial and gastric cancers have indicated that promoter $1 \mathrm{~B}$ is protected from methylation [7072]. It should be noted that transcription might also start from promoter $1 \mathrm{~B}$; however, the product is an inactive protein. Nevertheless, further study on promoter $1 \mathrm{~B}$ is recommended for a better understanding of the role of this promoter and its possible function in SCCE.

\section{Conclusion}

Achieving a comparable pattern of APC promoter hypermethylation in the high risk region for SCCE, could be an indication for common molecular alterations in the etiology of SCCE between this region and other parts of the world. In addition, it raises hope for achieving a common molecular marker. Nevertheless, further studies are required to be carried out both on APC and other candidate genes, either at epigenetic level or at other molecular levels such as mutational inactivation and loss of heterozygosity. Identifying correlation between differentiation status and APC promoter methylation in conjunction with lower survival rate of patients with hypermethylated $A P C$ promoter implies the importance of epigenetic control of tumor suppressor genes in the tumorigenesis of SCCE, as well as the significant indicatory role of APC hypermetylation for evaluating tumor malignancy and predicting survival of SCCE patients subsequent to treatment.

\section{Competing interests}

The authors declare that they have no competing interests.

\section{Authors' contributions}

FRJ was the project leader and directed the study. He is the corresponding author. $\mathrm{MZ}$ was the main investigator of the study, performed the experiments and assisted in the draft of the manuscript. MRA and NKN participated in data acquisition and generated experimental data. $\mathrm{RM}$ is director of DDRC and supporter of the study as well as the head of the research ethics committee. MY was involved in surgery and tissue preparation. All authors reviewed and approved the final manuscript.

\section{Acknowledgements}

We are grateful to Mr. Noraeen for his kind assistance in the process of study, Dr. Banoei for his valuable assistance with statistical analysis and Dr. Shariati for her kind assistance in the editing of manuscript. The research was financially supported by a grant from the National Institute of Genetic Engineering \& Biotechnology (NIGEB), Tehran, Iran. 


\section{References}

I. Mosavi-Jarrahi A, Mohagheghi MA: Epidemiology of esophagea cancer in the high-risk population of iran. Asian Pac J Cancer Prev 2006, 7(3):375-380

2. Mahboubi JKaE: Esophageal Cancer in the Caspian Littoral of Iran: Initial Studies. Science 1972, I 75(4024):846-853.

3. Saidi F, Malekzadeh R, Sotoudeh M, Derakhshan MH, Farahvash MJ, Yazdanbod A, Merat S, Mikaeli J, Sotoudehmanesh R, Nasseri-Moghadam S, et al.: Endoscopic esophageal cancer survey in the western part of the Caspian Littoral. Dis Esophagus 2002 , I 5(3):2|4-2| 8.

4. Saidi F, Sepehr A, Fahimi S, Farahvash MJ, Salehian P, Esmailzadeh A, Keshoofy M, Pirmoazen N, Yazdanbod M, Roshan MK: Oesophageal cancer among the Turkomans of northeast Iran. $\mathrm{Br} J$ Cancer 2000, 83(9): $1249-1254$

5. Munoz N: Epidemiological aspects of oesophageal cancer. Endoscopy 1993, 25(9):609-6I2.

6. Blot WJ, McLaughlin JK: The changing epidemiology of esophageal cancer. Semin Oncol 1999, 26(5 Suppl I5):2-8.

7. Devesa SS, Blot WJ, Fraumeni JF Jr: Changing patterns in the incidence of esophageal and gastric carcinoma in the United States. Cancer 1998, 83(1 0):2049-2053.

8. Tabernero J, Macarulla T, Ramos FJ, Baselga J: Novel targeted therapies in the treatment of gastric and esophageal cancer. Ann Oncol 2005, I 6( I I): I 740-I748.

9. Miyake S, Nagai K, Yoshino K, Oto M, Endo M, Yuasa Y: Point mutations and allelic deletion of tumor suppressor gene DCC in human esophageal squamous cell carcinomas and their relation to metastasis. Cancer Res 1994, 54(I I):3007-30 I0.

10. Sepehr A, Taniere P, Martel-Planche G, Zia'ee AA, Rastgar-Jazii F, Yazdanbod M, Etemad-Moghadam G, Kamangar F, Saidi F, Hainaut P: Distinct pattern of TP53 mutations in squamous cell carcinoma of the esophagus in Iran. Oncogene 200I, 20(50):7368-7374.

II. Boynton RF, Blount PL, Yin J, Brown VL, Huang Y, Tong Y, McDanie T, Newkirk C, Resau JH, Raskind WH, et al.: Loss of heterozygosity involving the APC and MCC genetic loci occurs in the majority of human esophageal cancers. Proc Natl Acad Sci USA 1992, 89(8):3385-3388.

12. Huang Y, Boynton RF, Blount PL, Silverstein RJ, Yin J, Tong Y, McDaniel TK, Newkirk C, Resau JH, Sridhara R, et al.: Loss of heterozygosity involves multiple tumor suppressor genes in human esophageal cancers. Cancer Res 1992, 52(23):6525-6530.

13. Mori T, Aoki T, Matsubara T, lida F, Du X, Nishihira T, Mori S, Nakamura $Y$ : Frequent loss of heterozygosity in the region including BRCAI on chromosome I7q in squamous cell carcinomas of the esophagus. Cancer Res 1994, 54(7): I638-1640.

14. Mori T, Miura K, Aoki T, Nishihira T, Mori S, Nakamura Y: Frequent somatic mutation of the MTS I/CDK4I (multiple tumor suppressor/cyclin-dependent kinase 4 inhibitor) gene in esophageal squamous cell carcinoma. Cancer Res 1994, 54(13):3396-3397.

15. Biramijamal F, Allameh A, Mirbod P, Groene HJ, Koomagi R, Hollstein $M$ : Unusual profile and high prevalence of p53 mutations in esophageal squamous cell carcinomas from northern Iran. Cancer Res 2001, 6 I(7):3119-3123.

16. Casson AG, Mukhopadhyay T, Cleary KR, Ro JY, Levin B, Roth JA: p53 gene mutations in Barrett's epithelium and esophageal cancer. Cancer Res 199I, 5 I ( 1 6):4495-4499.

17. Muzeau F, Flejou JF, Thomas G, Hamelin R: Loss of heterozygosity on chromosome 9 and pl 6 (MTSI, CDKN2) gene mutations in esophageal cancers. Int / Cancer 1997, 72(I):27-30.

18. Zhuang Z, Vortmeyer AO, Mark EJ, Odze R, Emmert-Buck MR, Merino MJ, Moon H, Liotta LA, Duray PH: Barrett's esophagus: metaplastic cells with loss of heterozygosity at the APC gene locus are clonal precursors to invasive adenocarcinoma. Cancer Res 1996, 56(9): 1961-1964.

19. Smith E, De Young NJ, Tian ZQ, Caruso M, Ruszkiewicz AR, Liu JF, Jamieson GG, Drew PA: Methylation of TIMP3 in esophageal squamous cell carcinoma. World I Gastroenterol 2008, | 4(2):203-210.

20. Guo M, Ren J, House MG, et al.: Accumulation of promoter methylation suggests epigenetic progression in squamous cell carcinoma of the esophagus. Clin Cacer Res 2006, | 2:45 | 5-4522.
21. Park HL, Kim MS, Yamashita K, Westra W, Carvalho AL, Lee J, Jiang WW, Baek JH, Liu J, Osada M, et al.: DCC promoter hypermethylation in esophageal squamous cell carcinoma. International journal of cancer 2008, I 22( I I ):2498-2502.

22. Lee EJ, Lee BB, Han J, et al.: CpG island hypermethylation of Ecadherin (CDHI) and integrin 4 is associated with recurrence of early stage esophageal squamous cell carcinoma. International journal of cancer 2008, I 23(9):2073-2079.

23. Brock MV, Gou M, Akiyama Y, Muller A, Wu TT, Montgomery E, Deasel M, Germonpre P, Rubinson L, Heitmiller RF, et al.: Prognostic importance of promoter hypermethylation of multiple genes in esophageal adenocarcinoma. Clin Cancer Res 2003. 9(8):2912-2919.

24. Eads CA, Lord RV, Wickramasinghe K, Long TI, Kurumboor SK, Bernstein L, Peters JH, DeMeester SR, DeMeester TR, Skinner KA, et al.: Epigenetic patterns in the progression of esophageal adenocarcinoma. Cancer Res 200I, 6 I (8):3410-34I8.

25. Ishii T, Murakami ], Notohara K, Cullings HM, Sasamoto H, Kambara T, Shirakawa Y, Naomoto Y, Ouchida M, Shimizu K, et al.: Oesophageal squamous cell carcinoma may develop within a background of accumulating DNA methylation in normal and dysplastic mucosa. Gut 2007, 56(I): |3-19.

26. Jin Z, Mori $Y$, Yang J, Sato F, Ito T, Cheng $Y$, Paun B, Hamilton JP, Kan $T$, Olaru $A$, et al:: Hypermethylation of the nel-like I gene is a common and early event and is associated with poor prognosis in early-stage esophageal adenocarcinoma. Oncogene 2007, 26(43):6332-6340.

27. Tycko B: Epigenetic gene silencing in cancer. J Clin Invest 2000, I 05(4):40 I-407.

28. Brabender J, Usadel H, Danenberg KD, Metzger R, Schneider PM, Lord RV, Wickramasinghe K, Lum CE, Park J, Salonga D, et al.: Adenomatous polyposis coli gene promoter hypermethylation in non-small cell lung cancer is associated with survival. Oncogene 200I, 20(27):3528-3532.

29. Brock MV, Hooker CM, Ota-Machida E, Han Y, Guo M, Ames S, Glockner S, Piantadosi S, Gabrielson E, Pridham G, et al.: DNA methylation markers and early recurrence in stage I lung cancer. The New England journal of medicine 2008, 358( I I): I I I8-II 28.

30. Ellinger ], El Kassem N, Heukamp LC, Matthews S, Cubukluoz F, Kahl P, Perabo FG, Muller SC, von Ruecker A, Bastian PJ: Hypermethylation of cell-free serum DNA indicates worse outcome in patients with bladder cancer. The Journal of urology 2008, I 79( I):346-352.

31. Karpinski P, Sasiadek MM, Blin N: Aberrant epigenetic patterns in the etiology of gastrointestinal cancers. Journal of applied genetics 2008, 49(I): I- I0.

32. Kawakami K, Brabender J, Lord RV, Groshen S, Greenwald BD, Krasna MJ, Yin J, Fleisher AS, Abraham JM, Beer DG, et al.: Hypermethylated APC DNA in plasma and prognosis of patients with esophageal adenocarcinoma. I Natl Cancer Inst 2000, 92(22): $\mid 805-1811$.

33. Bektas N, Donner A, Wirtz C, Heep H, Gabbert HE, Sarbia M: Allelic loss involving the tumor suppressor genes APC and MCC and expression of the APC protein in the development of dysplasia and carcinoma in Barrett esophagus. American journal of clinical pathology 2000, I | 4(6):890-895

34. Wang M, Lu R, Fang D: [The possible role of loss of heterozygosity at APC, MCC and DCC genetic loci in esophageal carcinoma]. Zhonghua Zhong Liu Za Zhi 1999, 2 I(I): I6-I8.

35. Li H, Lu S: [Mutation of tumor suppressor genes APC and MCC in human esophageal cancer]. Zhonghua zhong liu za zhi [Chinese journal of oncology] I995, I7(I):9-12.

36. Stoltzing O, Schneider PM, Becker K, Wegerer S, Siewert JR, Holscher $\mathrm{AH}$ : [Frequency and significance of APC gene mutations in malignant degeneration of Barrett esophagus]. Langenbecks Arch Chir Suppl Kongressbd 1998, I I 5(SuppI I):485-489.

37. Choi YW, Heath El, Heitmiller R, Forastiere AA, Wu TT: Mutations in beta-catenin and APC genes are uncommon in esophageal and esophagogastric junction adenocarcinomas. Mod Pathol 2000, I3(10): I055-1059.

38. Ogasawara S, Maesawa C, Tamura G, Satodate R: Lack of mutations of the adenomatous polyposis coli gene in oesophageal and gastric carcinomas. Virchows Arch 1994, 424(6):607-6I I. 
39. Powell SM, Papadopoulos N, Kinzler KW, Smolinski KN, Meltzer S]: APC gene mutations in the mutation cluster region are rare in esophageal cancers. Gastroenterology 1994, I 07(6): I 759-I 763.

40. Rocheleau CE, Downs WD, Lin R, Wittmann C, Bei Y, Cha YH, Ali $M$, Priess JR, Mello CC: Wnt signaling and an APC-related gene specify endoderm in early C. elegans embryos. Cell 1997. 90(4):707-7I6.

4I. Morin PJ, Sparks AB, Korinek V, Barker N, Clevers H, Vogelstein B, Kinzler KW: Activation of beta-catenin-Tcf signaling in colon cancer by mutations in beta-catenin or APC. Science 1997, 275(5307): $1787-1790$.

42. Clement G, Braunschweig R, Pasquier N, Bosman FT, Benhattar J: Alterations of the Wnt signaling pathway during the neoplastic progression of Barrett's esophagus. Oncogene 2006, 25(2I):3084-3092.

43. Wolff RK, Frazer KA, Jackler RK, Lanser MJ, Pitts LH, Cox DR: Analysis of chromosome 22 deletions in neurofibromatosis type 2-related tumors. Am J Hum Genet 1992, 5 I (3):478-485.

44. Herman JG, Jen J, Merlo A, Baylin SB: Hypermethylation-associated inactivation indicates a tumor suppressor role for p I 5INK4B. Cancer Res 1996, 56(4):722-727.

45. John SW, Weitzner G, Rozen R, Scriver CR: A rapid procedure for extracting genomic DNA from leukocytes. Nucleic Acids Res 1991, 19(2):408

46. Olek A, Oswald J, Walter J: A modified and improved method for bisulphite based cytosine methylation analysis. Nucleic Acids Res 1996, 24(24):5064-5066.

47. Engemann S, El-Maarri O, Hajkova P, Oswald J, Walter J: Bisulfitebased methylation analysis of imprinted genes. Methods $\mathrm{Mol}$ Biol 2001, 181:217-228.

48. Grunau C, Clark SJ, Rosenthal A: Bisulfite genomic sequencing: systematic investigation of critical experimental parameters. Nucleic Acids Res 200I, 29(13):E65-65.

49. Herman JG, Graff JR, Myohanen S, Nelkin BD, Baylin SB: Methylation-specific PCR: a novel PCR assay for methylation status of CpG islands. Proc Natl Acad Sci USA 1996, 93( I 8):982I-9826.

50. Hube F, Reverdiau P, lochmann S, Gruel Y: Improved PCR method for amplification of GC-rich DNA sequences. Molecular biotechnology 2005, 3 I (I):8I-84.

51. Nagai M, Yoshida A, Sato N: Additive effects of bovine serum albumin, dithiothreitol, and glycerol on PCR. Biochemistry and molecular biology international 1998, 44(I): 157-163.

52. Roux $\mathrm{KH}$ : Optimization and troubleshooting in PCR. PCR methods and applications 1995, 4(5):S185-194.

53. Raja S, Godfrey TE, Luketich JD: The role of tumor suppressor genes in esophageal cancer. Minerva chirurgica 2002, 57(6):767-780.

54. Eads CA, Lord RV, Kurumboor SK, Wickramasinghe K, Skinner ML, Long TI, Peters JH, DeMeester TR, Danenberg KD, Danenberg PV, et al: Fields of aberrant CpG island hypermethylation in Barrett's esophagus and associated adenocarcinoma. Cancer Res 2000, 60(I8):502I-5026.

55. Tarmin L, Yin J, Zhou X, Suzuki H, Jiang HY, Rhyu MG, Abraham JM, Krasna MJ, Cottrell J, Meltzer SJ: Frequent loss of heterozygosity on chromosome 9 in adenocarcinoma and squamous cell carcinoma of the esophagus. Cancer Res 1994 54(23):6094-6096.

56. Xing EP, Nie Y, Wang LD, Yang GY, Yang CS: Aberrant methylation of pI6INK4a and deletion of pI5INK4b are frequent events in human esophageal cancer in Linxian, China. Carcinogenesis 1999, 20(I):77-84.

57. Xing EP, Yang GY, Wang LD, Shi ST, Yang CS: Loss of heterozygosity of the $\mathbf{R b}$ gene correlates with $\mathbf{p R b}$ protein expression and associates with p53 alteration in human esophageal cancer. Clin Cancer Res I999, 5(5):|23|-|240.

58. Esteller M: Epigenetic gene silencing in cancer: the DNA hypermethylome. Human molecular genetics 2007, I6(Spec No I): R50-59

59. Michor F, Iwasa Y, Lengauer C, Nowak MA: Dynamics of colorectal cancer. Seminars in cancer biology 2005, I 5(6):484-493.

60. Kang GH, Lee S, Kim JS, Jung HY: Profile of aberrant CpG island methylation along multistep gastric carcinogenesis. Laboratory investigation; a journal of technical methods and pathology 2003, 83(4):519-526.

6I. Takahashi T, Shigematsu H, Shivapurkar N, Reddy J, Zheng Y, Feng Z, Suzuki M, Nomura M, Augustus M, Yin J, et al.: Aberrant promoter methylation of multiple genes during multistep pathogenesis of colorectal cancers. International journal of cancer 2006, I | 8(4):924-93।.

62. Laird PW, Jackson-Grusby L, Fazeli A, Dickinson SL, Jung WE, Li E, Weinberg RA, Jaenisch R: Suppression of intestinal neoplasia by DNA hypomethylation. Cell 1995, 8 I(2): |97-205.

63. Clément $\mathrm{G}$, Fontolliet $\mathrm{C}$, Pasquier $\mathrm{N}$, et al:: APC, hTERT and TIMP-3: New molecular markers to distinguish patients at risk for the development of Barrett's esophageal adenocarcinoma. Proc Amer Assoc Cancer Res 2004, 45:

64. Smeds J, Berggren P, Ma X, Xu Z, Hemminki K, Kumar R: Genetic status of cell cycle regulators in squamous cell carcinoma of the oesophagus: the CDKN2A (pI6(INK4a) and p I4(ARF)) and p53 genes are major targets for inactivation. Carcinogenesis 2002, 23(4):645-655.

65. Metzger R, Schneider PM, Warnecke-Eberz U, Brabender J, Holscher $\mathrm{AH}$ : Molecular biology of esophageal cancer. Onkologie 2004 27(2):200-206

66. Hu N, Huang J, Emmert-Buck MR, Tang ZZ, Roth MJ, Wang C, Dawsey SM, Li G, Li WJ, Wang QH, et al.: Frequent inactivation of the TP53 gene in esophageal squamous cell carcinoma from a high-risk population in China. Clin Cancer Res 2001, 7(4):883-89।

67. Sherr CJ: Principles of tumor suppression. Cell 2004, I I 6(2):235-246.

68. Nie Y, Liao J, Zhao X, Song Y, Yang GY, Wang LD, Yang CS: Detection of multiple gene hypermethylation in the development of esophageal squamous cell carcinoma. Carcinogenesis 2002, 23(10): $1713-1720$

69. Lambertz S, Ballhausen WG: Identification of an alternative 5' untranslated region of the adenomatous polyposis coli gene. Hum Genet 1993, 90(6):650-652.

70. Zysman M, Saka A, Millar A, Knight J, Chapman W, Bapat B: Methylation of adenomatous polyposis coli in endometrial cancer occurs more frequently in tumors with microsatellite instability phenotype. Cancer Res 2002, 62(13):3663-3666.

7I. Esteller M, Sparks A, Toyota M, Sanchez-Cespedes M, Capella G, Peinado MA, Gonzalez S, Tarafa G, Sidransky D, Meltzer SJ, et al.: Analysis of adenomatous polyposis coli promoter hypermethylation in human cancer. Cancer Res 2000 , 60( I 6):4366-437I

72. Tsuchiya T, Tamura G, Sato K, Endoh Y, Sakata K, Jin Z, Motoyama T, Usuba O, Kimura W, Nishizuka S, et al.: Distinct methylation patterns of two APC gene promoters in normal and cancerous gastric epithelia. Oncogene 2000, I9(32):3642-3646.

\section{Pre-publication history}

The pre-publication history for this paper can be accessed here:

http://www.biomedcentral.com/1471-2407/9/24/prepub

Publish with Biomed Central and every scientist can read your work free of charge

"BioMed Central will be the most significant development for disseminating the results of biomedical research in our lifetime. "

Sir Paul Nurse, Cancer Research UK

Your research papers will be:

- available free of charge to the entire biomedical community

- peer reviewed and published immediately upon acceptance

- cited in PubMed and archived on PubMed Central

- yours - you keep the copyright

Submit your manuscript here:

http://www.biomedcentral.com/info/publishing_adv.asp
BioMedcentral 